\title{
HUBUNGAN LINGKUNGAN FISIK RUMAH DENGAN KEJADIAN TUBERCULOSIS PARU
}

Tuti Lestiyaningsih ${ }^{1^{*}}$

${ }^{1 *}$ Department of Environmental Health, Poltekkes Kemenkes Tanjungkarang

\section{Artikel Info : \\ Received 21 Agustus 2020 Accepted 30 Desember 2020 Available online 31 Desember 2020}

Editor: Hajimi, Hajimi

Key word :

Tuberculosis, house, environment, ventilation

Kata Kunci :

Tb Paru,rumah,lingkungan, ventilasi,

\section{Ruwa Jurai: Jurnal}

Kesehatan Lingkungan is licensed under a Creative Commons Attribution-NonCommercial 4.0 International License.

\begin{abstract}
A b stract
Tuberculosis is an infectious disease caused by the bacteria Mycobacterium tuberculosis. Data from the Tanjung Sari Health Center in South Lampung Regency shows that there has been an increase in cases in the last two years, 46 cases in 2015 and 47 cases in 2016. Until the end of semester 1 of 2017, an additional 33 cases were recorded. This study aims to determine the relationship between sex and the physical environment of the house with the incidence of pulmonary tuberculosis at Tanjung Sari Public Health Center. This study used an analytic survey method with a case-control design. The population is people who are registered as patients of Tanjung Sari Public Health Center, from January to June 2017. The sample is 74 people, consisting of 37 cases and 37 controls. The results showed that women predominantly suffer from pulmonary tuberculosis. The physical environment includes the area of ventilation, the presence of cross-ventilation, and the position of the window as risk factors for pulmonary TB disease. It is recommended that people get used to opening windows to maintain the availability of fresh air in the room and the entry of sunlight. Puskesmas should increase the capacity of cadres in providing knowledge on the prevention of pulmonary tuberculosis to the community.
\end{abstract}

Tuberkulosis merupakan penyakit menular yang disebabkan oleh bakteri Mycobacterium tuberculosis. Data Puskesmas Rawat Inap Tanjung Sari Kabupaten Lampung Selatan menunjukkan terjadi peningkatan kasus dalam dua tahun terakhir, yaitu sebanyak 46 kasus pada tahun 2015, dan 47 kasus pada tahun 2016. Hingga akhir semester 1 tahun 2017, telah tercatat penambahan 33 kasus. Penelitian ini bertujuan untuk mengetahui hubungan antara jenis kelamin dan lingkungan fisik rumah dengan kejadian TB Paru di Puskesmas Tanjung Sari. Penelitian ini menggunakan metode survei analitik dengan rancangan case control. Populasi adalah masyarakat yang tercatat sebagai pasien Puskesmas Tanjung Sari, pada periode Januari sampai Juni 2017. Sampel sebanyak 74 orang, terdiri dari 37 kasus dan 37 kontrol. Hasil penelitian menunjukkan bahwa perempuan lebih mendominasi menderita Tb paru. Lingkungan fisik meliputi luas ventilasi, keberadaan ventilasi silang dan posisi jendela sebagai faktor risiko penyakit Tb paru. Disarankan agar masyarakat membiasakan diri membuka jendela untuk menjaga ketersediaan udara segar dalam ruangan dan masuknya sinar matahari. Puskesmas sebaiknya meningkatkan kapasitas kader dalam memberikan pengetahuan tentang pencegahan Tb paru kepada masyarakat.

* Corresponding author: Tuti Lestiyaningsih

Jl. Soekarno-Hatta No 6, Bandar Lampung, Provinsi Lampung

Email: tutilestiyaningsih@yahoo.com

\section{PENDAHULUAN}

Tuberkulosis merupakan penyakit menular yang disebabkan oleh bakteri Mycobacterium tuberculosis. Sebagian besar (80\%) bakteri ini menyerang organ paru-paru, sedangkan $20 \%$ lainnya menyerang organ lainnya. WHO menyatakan bahwa TB paru merupakan kedaruratan global bagi kemanusiaan sejak tahun 1993 (Kementerian Kesehatan RI, 2011). Menurut WHO pada tahun 2012, diperkirakan jumlah kasus TB paru di dunia 8,6 juta kasus. Dengan insiden sekitar 122 per 100.000 penduduk. Indonesia masuk dalam 10 negara dengan insiden TB paru tertinggi, mulai dari 
negara India, Cina, Afrika Selatan dan Indonesia (Dotulong et al., 2015).

Menurut Peraturan Menteri Kesehatan Republik Indonesia Nomor 67 tahun 2016 Tentang Penanggulangan Tuberkulosis (Tb) bahwa penyakit Tuberkulosis ( $\mathrm{Tb}$ ) merupakan penyakit menular yang masih menjadi masalah kesehatan masyarakat, dan salah satu penyebab kematian sehingga perlu dilaksanakan program penanggulangan $\mathrm{Tb}$ secara berkesinambungan. Tb mudah menular pada mereka yang tinggal diperumahan padat, kurang sinar matahari, dan sirkulasi udaranya buruk (Sejati \& Sofiana, 2015; sirait, 2018).

Puskesmas Rawat Inap Tanjung Sari Kecamatan Natar adalah salah satu puskesmas yang ada di Kabupaten Lampung Selatan. Berdasarkan dari data Seksi P2 Dinas Kesehatan Kabupaten Lampung Selatan, angka CNR Puskesmas sebesar 62 atau sebanyak 46 kasus pada tahun 2015, dan pada tahun 2016 mengalami peningkatan sebesar 84 atau sebanyak 47 kasus. Peningkatan jumlah kasus pada dua tahun terakhir membuktikan bahwa perkembangan $\mathrm{Tb}$ paru di Puskesmas Rawat Inap Tanjung Sari, Kecamatan Natar, Lampung Selatan terus meningkat dan harus diwaspadai. Penularan bakteri Mycobacterium tuberculosis melalui udara diantaranya dipengaruhi oleh lingkungan yang tidak baik, seperti kondisi ventilasi dan pencahayaan. Lingkungan fisik rumah yang telah diperiksa sejumlah 9.180 rumah dan yang memenusi syarat lingkungan fisik yang sehat sebanyak $42,40 \%$. Tujuan dari penelitian ini adalah mengetahui hubungan jenis kelamin dan lingkungan fisik rumah dengan kejadian Tb paru di Wilayah Kerja Puskesmas Tanjung Sari Kecamatan Natar Kabupaten Lampung Selatan.

\section{METODE}

Penelitian ini merupakan penelitian survei analitik dengan rancangan survei case control
Data yang diambil adalah data primer dan data sekunder. Penelitian ini dilaksanakan di Wilayah Kerja Puskesmas Tanjung Sari Kecamatan Natar Kabupaten Lampung Selatan dari bulan Januari sampai Juni 2017. Variabel penelitian adalah lingkungan fisik rumah (luas ventilasi, ventilasi silang, letak jendela kamar) dan kejadian TB paru.

Populasi dalam penelitian ini adalah masyarakat Desa Tanjung Sari Kecamatan Natar Kabupaten Lampung Selatan. Sampel dihitung menggunakan rumus sampel kasus control tidak berpasangan (Scheelsman), perkiraan OR menggunakan penelitian terdahulu. Hasil perhitungan sampel diperoleh 37 sampel kasus. Pada penelitian ini menggunakan perbandingan $1: 1$, sehingga sampel kasus berjumlah 37 responden dan sampel control berjumlah 37 responden.

Sampel kasus adalah orang yang telah didiagnosa oleh petugas kesehatan menderita Tb Paru dan berdomisili di Desa Tanjungsari, dengan kriteria inklusi telah didiagnosa oleh petugas kesehatan bahwa responden menderita TB paru, berdomisili di Desa Tanjungsari dan bersedia bekerja sama dengan peneliti. Sampel kontrol adalah tetangga kasus, dengan kriteria inklusi adalah tetangga kasus, tidak menderita Tb paru, dan bersedia ikut dalam penelitian.

\section{HASIL}

Berdasarkan pengumpulan dan analisa data yang telah dilakukan, hasil penelitian dapat disajikan sebagai berikut :

\section{Jenis Kelamin}

Tabel 1. menjelaskan distribusi jenis kelamin menurut kejadian TB paru. Pada kelompok kasus terdapat $48,6 \%$ responden berjenis kelamin lakilaki dan $62,2 \%$ berjenis kelamin perempuan, sedangkan pada kelompok kontrol ada 51,4\% responden dengan jenis kelamin laki-laki dan $37,8 \%$ perempuan.

Tabel 1. Hubungan Jenis Kelamin Dengan Kejadian Tb Paru

\begin{tabular}{|c|c|c|c|c|c|c|}
\hline \multirow{2}{*}{ Jenis Kelamin } & \multicolumn{2}{|c|}{ Kasus } & \multicolumn{2}{|c|}{ Kontrol } & \multirow{2}{*}{$\begin{array}{c}\text { P- } \\
\text { Value }\end{array}$} & \multirow{2}{*}{$95 \% \mathrm{Cl}$} \\
\hline & $\mathrm{N}$ & $\%$ & $\mathrm{~N}$ & $\%$ & & \\
\hline Laki-laki & 18 & 48,6 & 23 & 62,2 & \multirow{3}{*}{0,243} & \multirow{3}{*}{$\begin{array}{c}0,577 \\
0,228-1,455\end{array}$} \\
\hline Perempuan & 19 & 51,4 & 14 & 37,8 & & \\
\hline Jumlah & 37 & 100,0 & 37 & 100,0 & & \\
\hline
\end{tabular}


Hasil analisis secara bivariat menggunakan uji chi-square mendapatkan p-value 0,234 artinya tidak terdapat hubungan yang bermakna antara jenis kelamin dengan kejadian tuberculosis paru.

\section{Lingkungan fisik rumah}

Lingkungan fisik rumah yang dimaksud dalam penelitian ini meliputi luas ventilasi, keberadaan ventilasi silang dan letak jendela. Lingkungan fisik yang memenuhi syarat adalah luas ventilasi $\geq 10 \%$ dari luas lantai, terdapat ventilasi silang dan letak jendela menghadap ke Timur. Hasil analisis data terdapat pada tabel 2 .

Dari tabel 2. terlihat bahwa pada kelompok kasus, sebanyak 91,9\% responden tinggal pada rumah yang lingkungan fisiknya tidak baik dan
$8,1 \%$ tinggal pada rumah yang lingkungan fisiknya baik. Pada kelompok kontrol, 59,5\% responden tinggal pada rumah dengan lingkungan fisik yang tidak baik dan 40,5\% tinggal pada rumah dengan lingkungan fisik yang baik. Hasil uji statistik didapatkan nilai $p<0,05 \quad(p=0,003)$ Odds Ratio (OR) didapatkan 7,727 (Cl : 95\% : 2,002-29,826), dapat diartikan bahwa terdapat hubungan yang bermakna antara lingkungan fisik rumah dengan Tb paru. Responden yang tinggal pada rumah dengan lingkungan fisik tidak baik berpotensi menderita Tb paru sebesar 7,727 kali disbanding dengan responden yang tinggal pada rumah dengan lingkungan fisik baik.

Tabel 2. Hubungan Lingkungan Fisik Rumah Dengan Kejadian TB Paru

\begin{tabular}{|c|c|c|c|c|c|c|}
\hline \multirow{2}{*}{$\begin{array}{l}\text { Lingkungan Fisik } \\
\text { Rumah }\end{array}$} & \multicolumn{2}{|c|}{ Kasus } & \multicolumn{2}{|c|}{ Kontrol } & \multirow{2}{*}{$\begin{array}{l}P \text { - } \\
\text { value }\end{array}$} & \multirow{2}{*}{$\begin{array}{l}\text { OR } \\
(95 \% \mathrm{Cl})\end{array}$} \\
\hline & $\mathrm{N}$ & $\%$ & $\mathrm{~N}$ & $\%$ & & \\
\hline Tidak baik & 34 & 91,9 & 22 & 59,5 & \multirow{3}{*}{0,003} & \multirow{3}{*}{$\begin{array}{l}7,727 \\
(2,002-29,826)\end{array}$} \\
\hline Baik & 3 & 8,1 & 15 & 40,5 & & \\
\hline Jumlah & 37 & 100 & 37 & 100 & & \\
\hline
\end{tabular}

\section{PEMBAHASAN}

1. Jenis Kelamin

Hasil analisis menunjukkan tidak ada hubungan yang bermakna antara jenis kelamin dengan kejadian $\mathrm{Tb}$ paru di Wilayah Kerja Puskesmas Tanjungsari $(p=0,350)$. Hasil penelitian ini mengungkapkan bahwa kejadian Tb paru lebih banyak terjadi pada kelompok perempuan. Berbeda dengan hasil penelitian terdahulu. Penelitian Dotulong (2015) menyatakan bahwa jenis kelamin yang paling banyak menderita penyakit TB paru adalah kelompok laki-laki. Hasil penelitian Hiswani (2009) dalam Manalu (2010) juga menyatakan bahwa penderita TB paru cenderung lebih tinggi pada laki-laki dibandingkan perempuan. Pada jenis kelamin laki-laki penyakit ini lebih tinggi karena merokok tembakau dan minum alkohol sehingga dapat menurunkan sistem pertahanan tubuh, sehingga lebih mudah terpapar dengan agent penyebab TB paru. Selain itu, jenis kelamin mempengaruhi hubungan antara hemostasis dan luasnya lesi paru TB, yang mungkin merupakan salah satu mekanisme yang terlibat dalam jenis kelamin pada patogenesi TB (Tan et al., 2018).
Proporsi responden lebih didominasi oleh perempuan, dimana responden tersebut berperan sebagai ibu rumah tangga yang banyak menghabiskan waktunya untuk kegiatan di dalam rumah. Aktivitas sehari-hari di dalam rumah jika tidak didukung dengan lingkungan fisik rumah yang sehat dapat berisiko timbulnya penyakit TB paru. Namun, dengan kegiatan yang tidak terlalu banyak, perempuan memiliki waktu untuk pergi ke tempat pelayanan kesehatan sehingga kejadian Tb paru pada perempuan lebih dapat dideteksi dibadingkan laki-laki.

\section{Lingkungan Fisik rumah}

Beberapa faktor lingkungan fisik rumah mempunyai peranan yang sangat penting dalam penularan penyakit. Risiko berkembangnya penyakit ini bergantung pada faktor endogen, eksogen, dan lingkungan (Jurado \& Palacios, 2018). Kondisi rumah didukung lingkungan yang kurang memenuhi syarat kesehatan menjadi faktor risiko penularan penyakit $\mathrm{Tb}$ paru. Keadaan dinding rumah, pencahayaan, lantai rumah, ketersediaan udara segar didalam ruangan, ventilasi, posisi jendela dan faktor lingkungan lain memiliki peran terhadap penularan Tb paru. 
Dalam penelitian ini lingkungan fisik yang diukur adalah luas ventilasi, keberadaan ventilasi silang dan letak jendela. Lingkungan fisik dinyatakan memenuhi syarat jika luas ventilasi $\geq$ $10 \%$ dari luas lantai, terdapat ventilasi silang dan jendela menghadap ke arah timur. Hasil analisis mendapatkan 91,9\% responden tinggal pada rumah dengan kondisi lingkungan fisik tidak baik. Dari uji bivariat menggunakan chi-square didapatkan hasil ada hubungan yang bermakna antara lingkungan fisik rumah dengan kejadian TB paru $(p=0,003)$, responden yang tinggal pada rumah dengan lingkungan tidak baik berisiko 7,727 kali lebih besar untuk menderita Tb paru dibanding responden yang tinggal pada rumah dengan kondisi lingkungan baik.

Hasil penelitian sebelumnya mendukung hasil ini. Dalam penelitian Putra (2011) menyatakan kondisi ventilasi memiliki hubungan yang cukup kuat dengan terjadinya penularan penyakit TB paru, kondisi ventilasi merupakan faktor resiko dengan OR=5,714 (Putra, 2011). Menurut Peraturan Menteri Kesehatan Republik Indonesia Nomor 1077/Menkes/Per/V/2011 Tentang Pedoman Penyehatan Udara Dalam Ruang Rumah, salah satu syarat rumah yang sehat adalah rumah yang dilengkapi dengan ventilasi, minimal 10\%-20\% luas lantai dengan sistem ventilasi silang. Untuk memenuhi syarat, ventilasi harus memiliki ukuran minimal $10 \%$ dari luas lantai. Ventilasi merupakan lubang dimana cahaya dan udara dari luar bisa masuk kedalam ruangan. Adanya ventilasi memberikan celah masuknya cahaya sehingga ruangan menjadi terang, tidak pengap dan tidak lembab. Kondisi ventilasi rumah yang tidak memenuhi syarat, menghalangi masuknya cahaya matahari (Tobing, 2012).

Pada penelitian ini kondisi ventilasi rumah responden tidak memenuhi syarat karena sebagian besar kurang dari $10 \%$ luas lantai. Ventilasi yang cukup, akan menyediakan cahaya yang cukup pula didalam ruangan. Cahaya yang masuk akan membunuh Micobakterium tuberculosis yang terdapat didalam rumah. Ventilasi yang dibuat menghadap ke arah Timur, memberikan paparan matahari pagi yang cukup. Sinar matahari pagi baik untuk kesehatan dan menjadikan ruangan tidak lembab. Cahaya matahari yang tidak mencukupi akan mengakibatkan mikroba berkembangbiak dan memudahkan penularan kepada anggota keluarga yang lain. Kelembaban yang terlalu tinggi maupun rendah dapat menyebabkan suburnya pertumbuhan mikroorganisme.

Micobakterium tuberculosis merupakan mikroorganisme sebagai agent Tb paru masuk ketubuh manusia melalui pernafasan, selanjutnya menuju rongga pleura dan merusak jaringan pleura sehingga menimbulkan infeksi. Adanya infeksi menyebabkan penderita $\mathrm{Tb}$ memberikan gejala batuk. Ketika percikan air ludah keluar dan beterbangan di udara. Percikan air ludah tersebut mengandung basil TBC. Apabila diruangan ada orang lain yang sehat, maka akan terhisap oleh orang tersebut dan masuk ke dalam paru yang kemudian menyebabkan penyakit tuberculosis paru (Wikurendra, 2010).

Penelitian ini sejalan dengan penelitian Izzati et al. (2015), menyatakan bahwa responden yang memiliki ventilasi rumah tidak memenuhi syarat berisiko 1,8 kali lipat lebih besar untuk menderita TB paru dibandingkan dengan yang memiliki ventilasi rumah memenuhi syarat (Izzati et al., 2015). Sama halnya dengan penelitian Wulandari et al. (2015) Menyatakan bahwa terdapat hubungan yang bermakna antara ventilasi dengan kejadian tuberculosis paru di Kendal Jawa Tengah, Indonesia. (Wulandari et al., 2015).

Dalam kamar dengan luas ventilasi yang tidak mencukupi menyebabkan kuman selalu dalam konsentrasi tinggi sehingga memperbesar kemungkinan penularan kepada orang lain. Ventilasi rumah yang tidak cukup menghalangi aliran udara sehingga kelembaban udara didalam ruangan tidak terjaga. Kelembaban naik dan kondisi ini merupakan media yang baik bagi perkembangan kuman pathogen (Ihram, 2013).

Selain kondisi ventilasi, kepemilikan ventilasi silang merupakan salah satu syarat rumah sehat. Ventilasi silang memberikan jalan bertukarnya udara dari luar ruangan dengan udara di dalam ruangan. Menurut penelitian dari Texas Engineering Experiment Station tentang ventilasi silang, yaitu udara yang masuk dari satu jendela, akan langsung dialirkan ataupun diteruskan keluar oleh jendela yang berada dihadapannya, sehingga akan terjadi pergantian udara baru, begitu seterusnya. Dengan demikian maka udara dari dalam rumah yang mengandung kuman TB 
Paru (Mycobacterium tuberculosis) akan keluar dan langsung digantikan dengan udara baru yang segar.

Menurut Peraturan Menteri Kesehatan RI Nomor 1077/Menkes/Per/V/2011 tentang Pedoman Penyehatan Udara Dalam Ruang Rumah, salah satu syarat rumah yang sehat adalah rumah yang dilengkapi dengan ventilasi, minimal 10\%-20\% luas lantai dengan sistem ventilasi silang. Akan tetapi pada penelitian ini tidak didapatkan hubungan yang signifikan antara ventilasi silang dengan kejadian Tuberculosis Paru. Hal ini terjadi disebabkan oleh, responden memiliki ventilasi silang namun tertutup oleh lemari atau perabotan didalam rumah sehingga menghalangi masuknya udara dari luar. Bangunan yang berhimpitan juga dapat menghalangi masuknya udara.

Syarat rumah sehat selanjutnya adalah cukup sinar matahari. Menurut APHA (American Public Health Association), syarat rumah sehat adalah harus memenuhi persyaratan fisik, psikologi, pencegahan penularan penyakit dan pencegahan terhadap kecelakaan. Syarat fisik diantaranya adalah memiliki jendela dan ventilasi yang cukup, sedangkan syarat pencegahan terhadap penularan penyakit salah satunya dengan cukup sinar matahari pagi. Syarat fisik dan syarat pencegahan penyakit memiliki kaitan yang dapat diartinya bahwa kamar yang baik adalah kamar yang memiliki jendela menghadap ke arah timur, sehingga cukup sinar matahari pada pagi hari untuk membunuh kuman dalam ruangan.

Cahaya sangat dibutuhkan manusia dalam jumlah cukup kuat baik untuk penerangan di dalam rumah maupun menghangatkan ruangan. Cahaya alam dan cahaya buatan dapat digunakan sebagai sumber penerangan. Cahaya alamiah diperoleh dengan masuknya sinar matahari ke dalam ruangan melalui lubang jendela atau bagian lain dari ruangan yang terbuka. Bangunan dan pohon ataupun tembok bangunan yang tinggi dapat menghalangi sinar matahari yang masuk. Oleh karena itu, sebaiknya pada siang hari jendela untuk dibuka agar cahaya matahari dapat masuk selain itu udara dapat berputar sehingga udara kotor akan bertukar dengan udara bersih dengan demikian risiko terjadinya penularan penyakit akan diperkecil. Jendela kamar tidur akan lebih baik jika menghadap ke Timur. Pada pagi hari matahari terbit dari Timur, cahaya matahari secara optimal akan masuk ke kamar tidur. Luas jendela yang baik paling sedikit mempunyai luas 10-20\% dari luas lantai. Dengan luas tersebut sudah mencukupi dalam menciptakan kondisi hangat dan tidak lembab dalam ruangan. Apabila luas jendela melebihi 20\% dampaknya penghuni akan merasa kesilauan dan panas, sebaliknya kalau terlalu kecil dapat menimbulkan suasana gelap dan pengap.

Dalam ruang kediaman, diharapkan terdapat satu atau lebih banyak jendela/lubang yang bias dibuka dan ditutup sehingga langsung berhubungan dengan udara dan bebas dari rintangan-rintangan, jumlah luas bersih jendela/ lubang itu harus sekurang-kurangya sama 1/10 dari luas lantai ruangan, dan setengah dari jumlah luas jendela/lubang itu harus dapat dibuka. Jendela/lubang angin itu harus meluas kearah atas sampai setinggi minimal $1,95 \mathrm{~m}$ di atas permukaan lantai. Diberi lubang hawa atau saluran angin pada ban atau dekat permukaan langit-langit (ceiling) yang luas bersihnya sekurang-kurangnya 5\% dari luas lantai yang bersangkutan. Pemberian lubang hawa/saluran angin dekat dengan langit-langit berguna sekali untuk mengeluarkan udara panas dibagian atas dalam ruangan (Sabarudin et al., 2011).

Ketentuan luas jendela/lubang angin harus disesuaikan dengan kondisi iklim dan lokasi dimana daerah itu berada. Ketentuan diatas hanya sebagai pedoman yang umum Daerah pegunungan berhawa dingin dan banyak angin, apabila menggunakan ukuran standar dapat menyebabkan penghuninya menjadi terganggu kesehatannya. Maka luas jendela/lubang angin dapat dikurangi sampai dengan $1 / 20$ dari luas ruangan. Sedangkan untuk daerah pantai laut dan daerah rendah jumlah luas bersih jendela dan lubang angin harus diperbesar mencapai $1 / 5$ dari luas lantai ruangan karena berhawa panas dan basah.

Menurut teori cahaya dapat mempengaruhi pertumbuhan bakteri. Adanya sumber cahaya dalam ruangan dapat menghambat pertumbuhan bakteri. Pencahayaan harus cukup baik. Pada waktu pagi hari sinar matahari dapat menjadi sumber utama penerangan dalam ruangan. Paparan cahaya dengan intensitas sinar ultraviolet (UV) tinggi dapat berakibat fatal bagi pertumbuhan bakteri. Bakteri akan mengalami 
iradiasi yang berdampak pada kelainan dan kematian bakteri (Vindrahapsari, 2016).

Dalam PMK No. 1077 tahun 2011 tentang Pedoman Penyehatan Udara Dalam Ruang Rumah disebutkan bahwa pertukaran udara yang tidak memenuhi syarat dapat menyebabkan suburnya pertumbuhan mikroorganisme, yang mengakibatkan gangguan terhadap kesehatan manusia (Peraturan Mentri Kesehatan Indonesia No 1077/Menkes/PER/2011, 2011). Kurangnya ventilasi dalam hal jumlah dan dan luas merupakan factor risiko terjadinya penyakit infeksi, salah satunya adalah TB paru.

Rumah dengan pencahayaan dan ventilasi yang baik akan membuat pertumbuhan kuman menjadi sulit, kuman harus bertahan dengan sinar ultraviolet apabila tidak bias bertahan maka kuman akan mati. Ventilasi yang baik menyebabkan pertukaran udara sehingga mengurangi kosentrasi kuman (Ihram, 2013).

Kepada responden yang lingkungan fisik rumahnya tidak memenuhi syarat yaitu sebaiknya dibiasakan untuk membuka jendela setiap hari, agar udara segar masuk melalui jendela dan bukan hanya melalui lubang ventilasi. Kebiasaan membuka jendela kamar tidur dan membuka jendela ruang keluarga berkontribusi terhadap ketersediaan udara segar dalam ruangan (Ahyanti, 2020).

Pencegahan penularan Tuberculosis paru dapat dilakukan dengan modifikasi lingkungan oleh keluarga. Keadaan rumah yang sehat yang digambarkan dengan kondisi ventilasi yang memenuhi syarat sehingga pencahayaan yang masuk mencukupi, jendela yang dibuka setiap hari dapar membunuh mikroorgnisme pathogen yang ada didalam rumah (Lestari et al., 2019). Ventilasi tidak hanya dapat dibuat dibagian dinding saja. Bila tidak memungkinkan mendapatkan aliran udara dan cahaya dari ventilasi yang dibuat pada dinding, dapat dilakukan dengan membuat lubang ventilasi dibagian atap.

\section{SIMPULAN}

Walaupun perempuan lebih banyak penderita Tb paru, namun hasil penelitian tidak menunjukkan hubungan yang bermakna antara jenis kelamin dengan Tb paru. Lingkungan fisik manjadi faktor risiko terjadinya Tb paru. Disarankan untuk membiasakan membuka jendela setiap hari. Puskesmas dapat meningkatkan pemberdayaan masyarakat dengan melatih kader untuk memberikan pengetahuan kepada masyarakat tentang pencegahan $\mathrm{Tb}$ paru serta membagikan leaflet kepada masyarkat.

\section{DAFTAR PUSTAKA}

Ahyanti, M. (2020). Sanitasi Pemukiman pada Masyarakat dengan Riwayat Penyakit Berbasis Lingkungan Sanitation of Community Settlements with a History of EnvironmentalBased Diseases. Jurnal Kesehatan Poltekkes Tanjungkarang, 11(1), Hal. 44-50.

Dotulong, J. F. J., Sapulete, M. R., \& Kandou, G. D. (2015). Hubungan Faktor Risiko Umur, Jenis Kelamin Dan Kepadatan Hunian Dengan Kejadian Penyakit Tb Paru Di Desa Wori Kecamatan Wori. Jurnal Kedokteran Komunitas Dan Tropik, 3(2), Hal. 57-65.

Ihram, M. A. (2013). Hubungan Tingkat Sirkulasi Oksigen dan Karakteristik Individu dengan Kejadian TB Paru pada Kelompok Usia Produktif di Puskesmas Pondok Pucung Tahun 2013. In Fakultas Kedokteran dan Ilmu Kesehatan Universitas Negeri Syarif Hidayatullah. Fakultas Kedokteran dan IImu Kesehatan Universitas Negeri Syarif Hidayatullah. https://doi.org/10.35790/ebm.5.2.2017.18520

Izzati, S., Basyar, M., \& Nazar, J. (2015). Faktor Risiko yang Berhubungan dengan Kejadian Tuberkulosis Paru di Wilayah Kerja Puskesmas Andalas Tahun 2013. Jurnal Kesehatan Andalas, 4(1), 262-268. https://doi.org/10.25077/jka.v4i1.232 Jurado, L. F., \& Palacios, D. M. (2018). Tuberculosis: A Risk Factor Approach. In Tuberculosis. https://doi.org/10.5772/intechopen.73538

Kementerian Kesehatan RI. (2011). Pedoman Nasional Pengendalian Tuberculosis Tahun 2011. Dirjen Pengendalian Penyakit Dan Penyehatan Lingkungan:

Lestari, N. P., Wahyuni, N. S., \& Nasriati, R. (2019). Studi Kasus: Upaya Pencegahan Penularan Penyakit Pada Keluarga Dengan Penderita Tb Paru. Health Sciences Journal, 3(2), Hal. 43-55. https://doi.org/10.24269/hsj.v3i2.264

Peraturan Mentri Kesehatan Indonesia No 1077/Menkes/PER/2011, (2011).

Putra, N. R. (2011). Hubungan Perilaku Dan Kondisi Sanitasi Rumah Dengan Kejadian TB Paru Di Kota Solok Tahun 2011. Fakultas Kedokteran Universitas Andalas Padang. 
Sabarudin, A., Hartini, \& Hermawan, Y. (2011). Modul Rumah Sehat (p. Hal. 1-40). Badan penelitian dan Pengembangan, Pusat Penelitian dan Pengembangan Permukiman.

Sejati, A., \& Sofiana, L. (2015). Faktor-Faktor Terjadinya Tuberkulosis. Jurnal Kesehatan Masyarakat, 10(2), Hal. 122-128. https://doi.org/10.15294/kemas.v10i2.3372 sirait. (2018). Pengaruh Kepatuhan Dan Motivasi Penderita Tb Paru Terhadap Tingkat Kesembuhan Pengobatan Di Puskesmas Tanjung Morawa Kabupaten Deli Serdang Tahun 2017. Jurnal Kesehatan Masyarakat (eJournal), 1(1), Hal. 31-36.

http://ejournal.delihusada.ac.id/index.php/JPKS Y/article/view/40

Tan, W., Soodeen-Lalloo, A. K., Chu, Y., Xu, W., Chen, F., Zhang, J., Sha, W., Huang, J., Yang, G., Qin, L., Wang, J., Huang, X., Shi, J., \& Feng, Y. (2018). Sex influences the association between haemostasis and the extent of lung lesions in tuberculosis. Biology of Sex Differences, 9(1), 111. https://doi.org/10.1186/s13293-018-0203-9
Tobing, R. L. (2012). Hubungan Kesehatan Lingkungan Rumah terhadap Kejadian TB paru di Kecamatan Tretep Kabupaten Temanggung. Fakultas IImu Kesehatan.

Vindrahapsari, R. T. (2016). Kondisi Fisik dan Jumlah Bakteri Udara pada Ruangan AC dan Non AC di Sekolah Dasar (Studi Sekolah Dasar Sang Timur Semarang). In Universitas Muhammadiyah Semarang. Universitas Muhammadiyah Semarang. http://repository.unimus.ac.id/51/1/FULLTEXT 1.pdf

Wikurendra, E. A. (2010). Faktor Faktor Yang Mempengaruhi Kejadian Tb Paru Dan Upaya Penanggulangannya. Jurnal Ekologi Kesehatan, 9(4), Hal. 1340-1346. https://doi.org/10.31227/osf.io/r3fmq

Wulandari, A. A., Nurjazuli, \& Adi, M. S. (2015). Faktor Risiko dan potensi Penularan Tuberculosis Paru di Kabupaten kendal, Jawa Tengah. Jurnal Kesehatan Lingkungan Indonesia, 14(1), 382-386. https://doi.org/10.1299/kikaic.57.382 